\title{
Evaluation Rainfall Regime at the Hydroelectric Power Plant toward Climate Change
}

\author{
${ }^{*}{ }^{1}$ Francisco Pereira, ${ }^{2}$ Elison Eduardo Bierhals; ${ }^{3}$ José Leandro Néris, ${ }^{4}$ Matheus Rippel, \\ ${ }^{5}$ Claudinéia Brazil, 6 Luciane Salvi, ${ }^{7}$ Nei Marçal \\ 1, 2, 5 Energy Engineering, State University of Rio Grande do Sul, Brazil \\ 3,4,5,6 Environmental and Sanitary Engineering, Don Bosco College of Porto Alegre, Brazil \\ E mail: fbp.francisco@gmail.com ,E mail: edvardojb_energia@hotmail.com ,3E mail: matheuslrippel@gmail.com \\ 4E mail: leandro melgar@hotmail.com, 5E mail: $\underline{\text { neiabrazil@yahoo.com,6E mail: salvi.faculdade@dombosco.net }}$ \\ 7Email: marcalvergs@gmail.com
}

\begin{tabular}{l}
\hline A R T I C L E I N F O: \\
\hline Article history: \\
Received 2 August 2017 \\
Accepted 10 August 2017 \\
Available online 12 October \\
2017 \\
\hline Keywords: \\
Climate Change; \\
IPCC-AR5; \\
Precipitation.
\end{tabular}

This work is licensed under a Creative Commons Attribution NonCommercial - NoDerivs 4.0. "CC-BY-NC-ND"

\begin{abstract}
A B S T R A C T
The hydroelectric plants are first in the Brazilian energy matrix, so irregularities in the rainfall regime can affect the energy generation, thus evidencing the need to know the rainfall distribution in the studied area. This work aimed to evaluate possible analysis of the impacts of climate change on the rainfall regime in the Machadinho hydroelectric region. For the research development, the IPCC-AR5 pessimistic scenario was used, representing a scenario with a continuous population growth and high carbon dioxide emissions. From the historical series and organized projections, precipitation anomalies were calculated. Analyzing the difference between the average of the month and the climatological normal, it was inferred that the model used presented a positive trend for precipitation in the period from $2026-2100$, projecting anomalies between 25 and $200 \mathrm{~mm}$ per month. A greater amplitude is observed in the precipitation of 2076-2100, indicating an increase in the occurrence of extreme events of precipitation, mainly in the spring period. Considering that the rains in the Machadinho hydroelectric region are increasing in the scenarios analyzed, the average water level in the reservoir of the plant tends to increase. JOURNAL OF CONTEMPORARY URBAN AFFAIRS (2017) 1(3), 62-65.
\end{abstract}

https://doi.org/10.25034/ijcua.2018.3682

www.ijcua.com

Copyright (C) 2017 Journal Of Contemporary Urban Affairs. All rights reserved.

\section{Introduction}

The global concern about climate change has been increasing, since the emission of gases from human activities contributes to the greenhouse effect in the atmosphere, indicating significant impacts to the planet in the coming years. The changes have been associated with the issue of energy, especially renewable energies, which are directly linked to climate variations. According to Moraes (2013) in 1988, the Intergovernmental Panel on Climate Change (IPCC) was created through an initiative of the
World Meteorological Organization (WMO) and the United Nations Environment Program (UNEP). The IPCC was established with the mission of evaluating research, interpreting it, and gathering all relevant information, both technical, scientific and socioeconomic, into comprehensive, easily understood and accessible reports by all in communities,

\section{*Corresponding Author:}

Energy Engineering, State University of Rio Grande do Sul, Brazil

E-mail address: fbp.francisco@gmail.com 
including decision makers (Grimm, 2016; Moraes, 2013). According to Nimer (1989), rainfall occurred in Brazil's southern region between 1990 and 2005 can be described as well distributed, with maxima ranging from 1200 to $2100 \mathrm{~mm} /$ year.

The hydroelectric plants are in the first position in the Brazilian energy matrix, evidencing, therefore, the need to know the distribution of the pluviometric regime of the region. The main objective of this work is to present an analysis of the impacts of climate change on rainfall in the Machadinho's hydroelectric power plant region, which has an installed capacity of 1,140 MW and is located in the states of Santa Catarina and Rio Grande do Sul.

\section{Material and Methods}

\subsection{Study area description}

An evaluation of precipitation projections in the region of the Machadinho Hydroelectric Power Plant, located in the Uruguay River basin (Figure 1). According to Schork et. Al. (2012), a Machadinho Hydroelectric Power Plant is located in the states of Santa Catarina and the Rio Grande do Sul between latitudes $27^{\circ} 31$ 'and $27^{\circ} 46^{\prime}$ south and longitudes $51^{\circ} 47$ 'and $51^{\circ} 11^{\prime}$ west.

The Basin extends between the parallels of $27^{\circ}$ and $34^{\circ}$ South latitude and the meridians of $49^{\circ} 30$ 'and $58^{\circ} 5^{\prime} \mathrm{W}$. It covers an area of approximately $384,000 \mathrm{~km} 2$, of which 174,494 $\mathrm{km} 2$ are located in Brazil, equivalent to $2 \%$ of the Brazilian territory. According to Andreolli ,(2003) its Brazilian portion is in the southern region, comprising $46,000 \mathrm{~km} 2$ of the State of Santa Catarina and $130,000 \mathrm{~km} 2$ in the State of Rio Grande do Sul. It is bordered to the north and northeast by the Serra Geral, to the south by the border with the Eastern Republic of Uruguay, east by the Central Depression Riograndense and the west by Argentina.
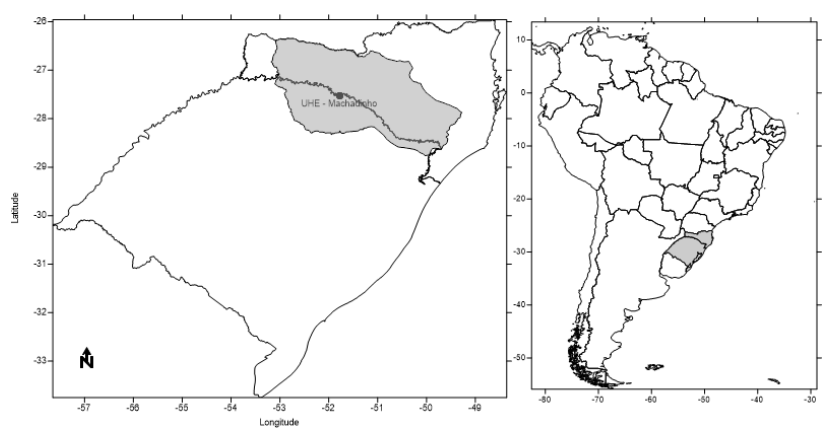

Figure 1. Study area localization.

\subsection{Data description and climate model}

The scenarios were generated using the models used in the Fifth Report of the Intergovernmental Panel on Climate Change (IPCC-AR5), based on an analysis of the seasonal variability of precipitation and the consequent variation in energy production.

The database used in this research is part of the Phase 5 Intercomparison of Matching Models (CMIP5) and contributed to the preparation of the fifth IPCC-AR5 report. The data were extracted from ACCESS model (The Australian Community Climate and Earth System Simulator). According to Van Vuuren et al., (2011) in AR5 the scenarios are organized according to the RCPs. In this research, RCP 8.5 scenario was used which represents a scenario with a continuous population growth, resulting in high carbon dioxide emissions, with an increase Up to $4^{\circ} \mathrm{C}$.

According to Silveira et al, (2016), this scenario is considered to be the most pessimistic for the $21 \mathrm{st}$ century in terms of greenhouse gas emissions, consistent with no policy change to reduce emissions and strong reliance on fossil fuels. The climatic projections of the precipitation series were divided into three scenarios: Scenario-1 (2026-2050), Scenario-2 (2051-2075) and Scenario-3 (2076-2100), the seasonal analysis was done for each of these scenarios.

\section{Methodology}

The monthly precipitation data were extracted from the IPCC-AR5 database, the information is provided in grid points, and Grads (Grid Analysis and Display System) software were used to extract the results. According to Souza (2004) Grads is a system of visualization and analysis of data in grid points, it works with binary data matrices, in which the variables can have up to four dimensions (longitude, latitude, vertical levels and time). After this stage, the historical data series and the data series with the climatic projections were organized. The projections were divided into three 25-year scenarios: Scenario-1 (2026-2050), Scenario-2 (2051-2075) and Scenario-3 (2076-2100). In the sequence precipitation anomalies were calculated from the following equation:

$$
\text { Apre }(\%)=\left(\left(P_{M M}-P_{M N}\right) / P_{M N}\right)^{*} 100
$$

Which:

Apre (\%) is the precipitation anomaly in percentage;

$\mathrm{P}_{M M}$ is the mean precipitation of the analyzed month; 
$\mathrm{P}_{\mathrm{MN}}$ is the climatological norm corresponding to the analyzed month.

World Meteorological Organization (WMO) defines climatological normal as averages of climatological data calculated for consecutive periods of 30 years.

\section{Results and Discussions}

The permanence curve is important for the study of precipitation variability, being possible to verify the probability of occurrence of the events that occur in the watershed. The figures show the permanence curves for Station 1 (Figure 3a) located at $-26.25^{\circ}$ latitude and $-52.50^{\circ}$ longitude and for station 2 (Figure 3b) located at $-27.50^{\circ}$ latitude And $-50.63^{\circ}$ longitude. In both stations, the trend in the increase of monthly average rainfall for the three scenarios was observed. Analyzing the third scenario of Posto 1, precipitation projections indicated an increase of around $400 \mathrm{~mm}$, compared to scenarios 1 and 2. In relation to the lower precipitation rates scenario 1 presented values below $200 \mathrm{~mm}$ in $70 \%$ of the analyzed period. For station 2 , the maximum precipitation presented values ranging from 600 to $900 \mathrm{~mm}$ around $5 \%$ of the time.

a)

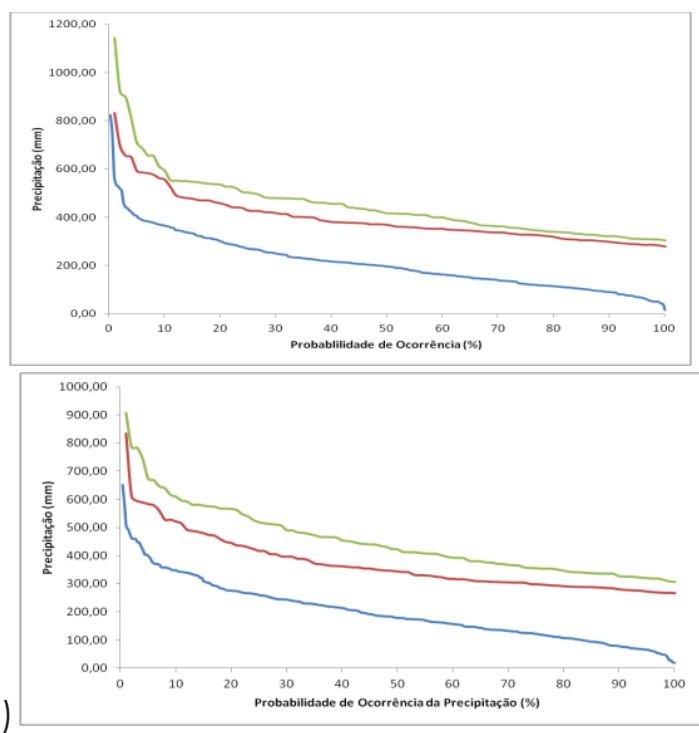

Figure 3. Permanence curve of precipitation projections for scenario 1 (blue line); Scenario 2 (red line); Scenario 3 (green line): a) Post 1 and b) Post 2

Figure 4 shows the positive anomalies in the two stations analyzed indicating a significant increase of the precipitation, mainly for the spring period, with an increase of around 200 $\mathrm{mm}$, for the third scenario. Summer was the period that indicated the smallest increase in precipitation, with values around $30 \mathrm{~mm}$ above the climatological norm.

a)

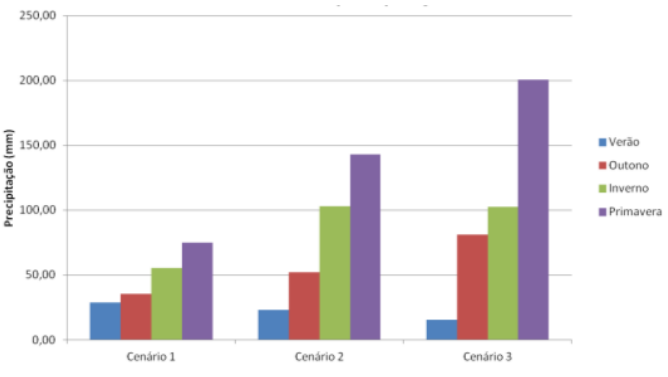

b)

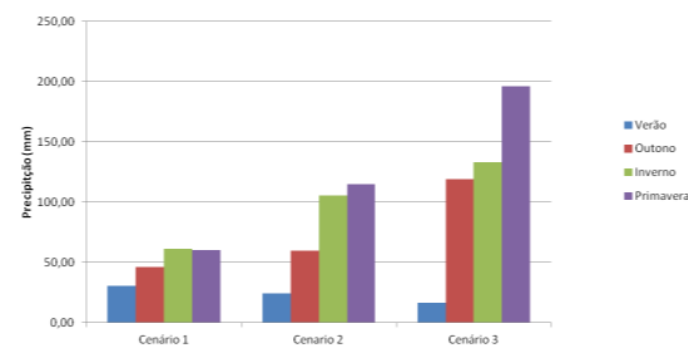

Figure 4. Seasonal Precipitation Anomalies: a) station 01 and b) station 02

Based on the average precipitation projections of the hydrographic basin where the Machadinho HPP is located, it was observed that the highest values of precipitation are found in the western half of the basin, fluctuating around $200 \mathrm{~mm}$ for scenario 1 (Figure 5a) .

Scenario 2 (Figure 5b) presented a precipitation projection around $238 \mathrm{~mm}$ and an increment around $64 \mathrm{~mm}$ for scenario 3 (Figure $5 c$ ), in relation to the first scenario analyzed, thus verifying a tendency in the increase of precipitation For the three scenarios in the Hydrographic Region of the Machadinho Hydroelectric Power Plant. 


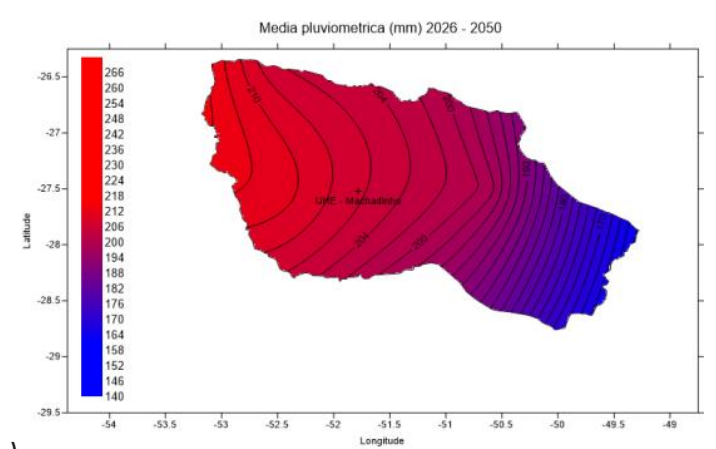

a)

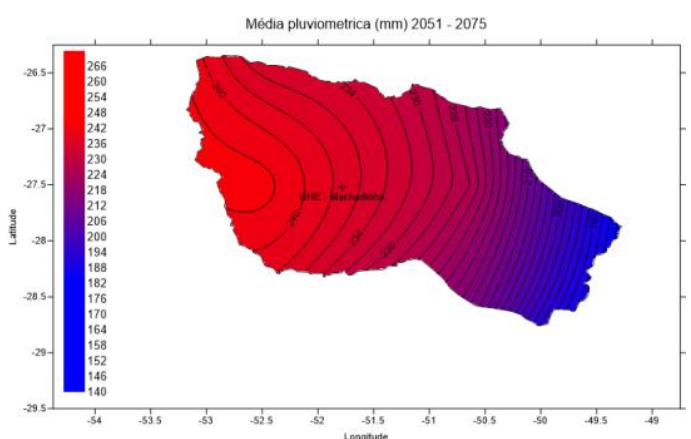

b)

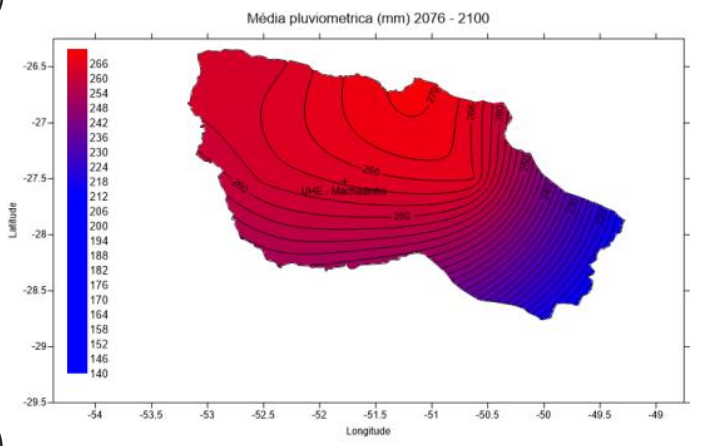

C)

Figure 5. Precipitation projections: a) Scenario 1 (2026 - 2050; b) Scenario 2 (2051 - 2075); C) Scenario 3 (2076 - 2100).

\section{Conclusion}

The hydroelectric plants are in the first position in the Brazilian energy matrix, evidencing, therefore, the need to know the distribution of the pluviometric regime of the region. The model analyzed in this article presented a positive trend for precipitation in the period from 2026 to 2100 , designing anomalies between 25 and $200 \mathrm{~mm}$ in each 24 - year period for the precipitation variable. A greater amplitude is observed in the precipitation of 2076-2100, indicating an increase in the occurrence of major precipitation events, mainly in the spring period, considering that the rains in the Machadinho HPP region are increasing in the scenarios analyzed, it is concluded That the level of the reservoir of the plant tends to increase, changing the pluviometric regime of the region.

\section{Acknowledgement}

This research did not receive any specific grant from funding agencies in the public, commercial, or not-for-profit sectors.

\section{References}

Ivanilto,A.(2003). Previsão de vazão em tempo real no Rio Uruguai com base na previsão meteorológica. Dissertação de Mestrado. Universidade Federal do Rio Grande do Sul.

Grimm, I. J. (2016). Mudanças Climáticas e Turismo: estratégias de adaptação e mitigação. Tese de Doutorado, Pósgraduação em Meio Ambiente e Desenvolvimento da Universidade Federal do Paraná. Curitiba, 248.

Moraes,F.(2013). Entenda como são feitos os relatórios do IPCC. Disponível em: <http://www.oeco.org.br/dicionarioambiental/27621-entenda-como-sao-feitosos-relatorios-do-ipcc/>. Acesso em: 06 maio 2016.

Nimer, E. (1989) Climatologia do Brasil.(2nd edition). Rio de Janeiro: IBGE.

Schork, G.,Hermes-Silva, S., Beux, L. F., ZaniboniFilho, E., Nuñer, A. P. O. (2012). Diagnóstico da pesca artesanal na usina hidrelétrica de Machadinho, alto rio Uruguai - Brasil. Bol. Inst. Pesca, São Paulo, 38(2),97-108.

Silveira,S.S., Souza Filho, F., Martins, E. S., Oliveira, J., Costa, Alexandre, Nobrega, M., Souza, S. A. (2011). Climate change in the São Francisco river basin: analysis of precipitation and temperature. RBRH, 21, 416-428. Porto Alegre abr. /jun. 2016.

Van Vuuren, D. P., Edmonsds, J., Kainuma, M., Riahi, K., Thomsonm, A., Hibbard, K., Hurtt, G. C., Kram T., Krey, V., Lamarque, J. F., Masui, T., Meinshausen, M., Nakicenovic, N., Smith, S. J., Rose, S. K. (2011). The representative concentration pathways: an overview. Climatic Change, 109, 5-31. 